\title{
PENGARUH PERENCANAAN DAN PERAMALAN UNTUK MEMBANGUN KOMITMEN KARYAWAN PADA PT. BPRS SARANA PRIMA MANDIRI PAMEKASAN
}

\author{
Zef Rizal \\ Nurul Fatimah \\ Universitas Madura
}

\section{ABSTRAK}

Masalah pokok dalam penelitian ini adalah apakah perencanaa dan peramalan berpengaruh terhadap komitmen karyawan pada PT. BPRS SARANA PRIMA MANDIRI Pamekasan. Diantara perencanaan dan peramalan manakah yang paling dominan berpengaruh terhadap komitmen karyawan PT. BPRS SARANA PRIMA MANDIR Pamekasan. Metode penelitian yang digunakan dalam penelitian ini yaitu dengan menggunakan angket atau kuesioner yang dibagikan kepada 43 karyawan serta melakukan wawancara langsung kepada pihak-pihak yang terkait dalam penelitian ini. Dari pengujian tersebut telah diperoleh data yang valid dan reliabel sehingga dapat dilanjutkan dengan analisis selanjutnya yaitu dengan teknik analisa regresi linear berganda serta uji T dan uji F dengan bantuan SPSS.Berdasarkan hasil penelitian ditemukan bahwa variabel perencanaan (X1) dan peramalan (X2) secara bersama-sama mempengaruhi variabel terikat yaitu komitmen karyawan (Y) dapat dibuktikan kebenarannya. Sedangkan hasil pengujian secara parsial (uji T) T hitung untuk variabel perencanaan (X1) sebesar 3,623 dan peramalan (X2) sebesar 2,624 dan kalau dikonsultasikan dengan $T$ tabel sebesar 2,021 sehingga $\mathrm{T}$ hitung $>\mathrm{T}$ tabel. Dengan demikian dapat disimpulkan bahwa variabel perencanaan (X1) dan peramalan (X2) berpengaruh terhadap komitmen karyawan(Y) dapat dibuktikan kebenarannya.

Keyword : perencanaan dan peramalan, komitmen karyawan

\section{PENDAHULUAN}

Perusahaan PT. BPRS SARANA PRIMA MANDIRI pamekasan ini merupakan salah satu jenis perusahaan perbankan yang diizinkan beroperasi dengan sistem syariah yang terletak di Jl. Agus Salim 20 pamekasan. Perusahaan perbankan Syariah ini terfokus untuk melayani Usaha Mikro dan Kecil yang menginginkan proses mudah, dengan pelayanan yang cepat dan persyaratan yang ringan.

Perusahaan perbankan syariah ini memiliki petugas yang berfungsi sebagai armada antar jemput setoran dan penarikan tabungan/deposito termasuk setoran angsuran pembiayaan. Perusahaan perbankan syariah ini mengelola dana masyarakat dengan sistem bagi hasil. Dengan sistem bagi hasil, masyarakat penyimpan dana akan mendapatkan bagi hasil secara fluktuasi karena sangat bergantung kepada pendapatan yang diperoleh perusahaan Dan sudah disepakati pada awal transaksi.

Untuk mempersiapkan sumber daya manusia tidak hanya dilihat dari segi kuantitasnya saja,sebab tersedianya sumber daya manusia yang cukup banyak belum tentu merupakan jaminan bahwa hasil yang dicapai akan efisien dan efektif.Sebagai langkah awal untuk mendapatkan sumber daya manusia yang berkualitas adalah dimulai dengan menarik dan memilih tenaga kerja yang sesuai dengan standar personalia dan sesuai dengan situasi dan kondisi perusahaan pada saat itu.

Standar ini merupakan persyaratan minimal yang harus dipenuhi agar seorang karyawan bisa mengerjakan pekerjaan-pekerjaannya dengan baik dengan cara melakukan proses 
perekrutan dan seleksi karyawan terlebih dahulu.Hal ini dirasa perlu mengingat sektor kredit merupakan sektor yang cukup mengandung banyak resiko (Hakim, 2011).

Sebelum suatu perusahaan atau organisasi melakukan perekrutan karyawan akan lebih baik terlebih dahulu perusahaan membuat perencanaan dan peramalan terhadap karyawan baru, agar perusahaan bisa mendapatkan tenaga kerja yang mempunyai komitmen siap untuk bekerja. Perencanaan awal yang dilakukan oleh perusahaan yaitu (1). Dengan menaruk pengumuman lowongan pekerjaan di situs internet dan melalui karyawan yang sudah bekerja di bank (2). Setelah semua surat lamaran masuk maka perusahaan akan melakukan memilih tenaga kerja (3). Setelah memilih surat lamaran yang masuk tahap selanjutnya adalah menyeleksi karyawan, dalam penyeleksian ada beberapa tahap yang akan dilakukan perusahaan 1, wawancara tenaga kerja pertama 2 , ujian tertulis 3 , wawancara kedua 4 , medical test 5, wawancara dengan atasan langsung 6, keputusan dari perusahaan diterima atau tidaknya.Perencanaan perekrutan karyawan ini sangat penting, jika terjadi kesalahan pada saat perekrutan karyawan dan penyeleksian tidak sesuai dengan pendidikan yang dimiliki tenaga kerja maka akan berpengaruh pada perusahaan,bisa mengakibatkan menurunnya sumber daya manusia di perusahaan itu.

Dalam memenuhi kebutuhan tenaga kerja di masa yang akan datang, perencanaan SDM lebih menekankan adanya usaha peramalan mengenai ketersediaan tenaga kerja yang didasarkan pada kebutuhan sesuai dengan rencana bisnis di masa yang akan datang. Perusahaan sudah meramalkan beberapa tahun yang lalu tentang perekrutan da penyeleksian karyawan dimasa yang akan datang. Dengan adanya peramalan yang baik perusahaan bisa merekrut tenaga kerja yang efektif ,efisien dan memiliki komitmen dalam bekerja.

Komitmen kerja bagi karyawan sangat diperlukan agar mereka memberikan hasil terbaik bagi organisasi atau perusahaan. Kompetensi tanpa komitmen sama dengan sebuah pistol berpeluru tetapi tidak bisa ditembakkan. Ada beberapa Karyawan diperusahaan perbangkan syariah ini yang memiliki suatu komitmen dalam bekerja, mereka berjanji akan bekerja secara total, mencurahkan perhatian, pikiran, tenaga dan waktunya, mereka mengerjakan apa yang diharapkan oleh perusahaan mereka juga bekerja dengan tim secara baik. Tujuan mereka membuat komitmen dalam bekerja agar mereka medapatkan promosi jabatan, dan gajinya bisa naik dengan hasil pekerjaan yang efektif.

Komitmen karyawan merupakan kondisi di mana pegawai sangat tertarik terhadap tujuan, nilai-nilai, dan sasaran organisasinya. Komitmen karyawan lebih dari sekedar keanggotaan formal, karena meliputi sikap menyukai organisasi dan kesediaan untuk mengusahakan tingkat upaya yang tinggi bagi kepentingan organisasi demi pencapaian tujuan. Jadi komitmen karyawan mencakup unsur loyalitas terhadap organisasi, keterlibatan dalam pekerjaan, dan identifikasi terhadap nilai-nilai dan tujuan organisasi.

Di samping itu komitmen karyawan mengandung pengertian sebagai suatu hal yang lebih dari sekedar kesetiaan yang pasif melainkan menyiratkan hubungan pegawai dengan perusahaan secara aktif. Karena pegawai yang menunjukkan komitmen tinggi memiliki keinginan untuk memberikan tenaga dan tanggungjawab yang lebih dalam menyokong kesejahteraan dan keberhasilan organisasinya. Apalagi ditambah dengan kondisi ekonomi yang serba tidak pasti dan inflasi yang termasuk masalah krusial di negara berkembang seperti Indonesia (Hakim, 2016).

Di dalam perusahaan perbankan ini jika pekerjaan karyawannya bagus dan efektif sesuai dengan yang diharapkan perusahaan maka bisa menaikkan gajinya, dan jika melebihi dari target pekerjaan karyawan tersebut bisa mendapatkan promosi jabatan ke jabatan yang lebih tinggi. 
Seperti halnya pada PT.BPRS SARANA PRIMA MANDIRI pamekasan merupakan obyek dalam penelitian ini sangat penting untuk memperhatikan bagaimana komitmen karyawan dalam menjalankan tugas dan tanggung jawab yang di berikan oleh perusahaan dengan baik.

\section{TINJAUAN PUSTAKA}

\section{- Perencanaan Sumber Daya Manusia}

Perencanaan sumber daya manusia akan dapat dilakukan dengan baik dan benar jika perencanaanya mengetahui apa dan bagaimana sumber daya manusia itu. Sumber daya manusia atau man power di singkat SDM merupakan kemampuan yang di miliki setiap manusia. Tegasnya kemampuan manusia di tentukan oleh daya pikir dan daya fisiknya. SDM/manusia menjadi unsur pertama dan utama dalam setiap aktivitas yang di lakukan. Peralatan yang canggih tanpa peran aktif SDM tidak berarti apa-apa.

Perencanaa sumber daya manusia atau Human Resources Planning disingkat PSDM merupakan fungsi pertama dan utama dari manajemen sumber daya manusia. PSDM diproses oleh perencana (planner) dan hasilnya menjadi rencana (plan).

Dalam rencana ditetapkan tujuan dan pedoman pelaksanaan serta menjadi dasar kontrol. Tanpa rencana, kontrol tak dapat dilakukan, dan tanpa kontrol, pelaksanaan rencana baik ataupun salah tidak dapat diketahui.

Menurut GeorgeTerry dalam

bukunyaMalayu S.P

Hasibuan,(2012:249), "perencanaan adalah memilih dan menghubungkan fakta dan membuat serta menggunakan asumsi-asumsi mengenai masa yang akan datang dengan jalan menggambarkan dan merumuskan kegiatan-kegiatan yang diperlukan untuk mencapai hasil yang diinginkan".

Menurut Billy E. Goetz dalam bukunya Malayu S.P Hasibuan(2012:249), "perencanaan adalah pemilihan yang fundamental dan masalah perencanaan timbul, jika terdapat alternatif-alternatif.Rencana di artikan sebagai pernyataan dari segala sesuatu yang dikehendaki yang di gambarkan dalam suatu pola atau petapeta, chart, atau pernyataan dari bagianbagiannya sesuai dengan pola tertentu".

Menurut Malayu S.P. Hasibuan (2012:249), "rencana ialah sejumlah keputusan yang menjadi pedoman untuk mencapai suatu tujuan tertentu. Jadi setiap rencana mengandung dua unsur yaitu tujuan dan pedoman". Perencanaan sumber daya manusia atau perencanaan tenaga kerja didefinisikan sebagai proses menentukan kebutuhan akan tenaga kerja dan cara memenuhi kebutuhan tersebut untuk melaksanakan rencana terpadu organisasi.

MenurutSedarmayanti(2007:131) "perencanaan adalah mengembangkan rencana pengembangan karyawan yang menunjang strategi organisasi yang ada melalui pengisian lowongan kerja secara proaktif".

MenurutVeithzal Rivai, (2013:32) "perencanaan adalah sebagai proses mengenai pembuatan kebijakan baru, sistem dan program yang menjamin pengolahan SDM di bawah kondisi yang tidak pasti (cepat berubah)".

\section{- Prosedur Perencanaan SDM :}

1.Menetapkan secara jelas kualitas dan kuantitas SDM yang dibutuhkan. 2. Mengumpulkan data dan informasi tentang SDM.

3.Mengelompokkan data dan informasi serta menganalisisnya.

4. Menetapkan beberapa alternative. 5. Memilih yang terbaik dari alternative yang ada menjadi rencana.

6. Menginformasikan rencana kepada para karyawan untuk direalisasikan.

Metode PSDM ,dikenal atas metode nonilmiah dan metode ilmiah. Metode nonilmiah diartikan bahwa perencanaan SDM hanya didasarkan atas pengalaman, imajinasi, dan perkiraan-perkiraan dari perencanaanya saja. Rencana SDM semacam ini risikonya cukup besar, misalnya kualitas dan kuantitas tenaga kerja tidak sesuai dengan kebutuhan perusahaan.

Akibatnya timbul mismanajemen dan pemborosan yang merugikan perusahaan. Metode ilmiah diartikan bahwa PSDM dilakukan berdasarkan atas hasil analisis dari data, informasi, 
dan peramalan (forecasting) dari perencananya. Rencana SDM semacam ini risikonya relative kecil karena segala sesuatunya telah diperhitungkan terlebih dahulu.

\section{- Syarat- Syarat Perencanaan SDM}

1. Harus mengatahui secara jelas masalah yang akan direncanakannya.

2. Harus mampu mengumpulkan dan menganilisis informasi tentang SDM.

3. Harus mempunyai pengetahuan luas tentang job analisis, organisasi dan situasi persediaan SDM.

4. Harus mampu membaca situasi SDM masa kini dan masa mendatang.

\section{- Pentingnya Perencanaan Sumber Daya Manusia}

Perencanaan SDM (Manpower Planning) adalahhal paling awal yang dilakukanolehperusahaanuntuk membentuk manajemen SDM yang baik.Perencanaan SDM meliputihal-hal detail danteknismengenaikaryawan. Misalnyajumlahkaryawan, karakteristikkebutuhankaryawan, danperencanaanmengenaitugasapa yang akandikerjakanolehkaryawan di perusahaantersebut. Berikut adalah beberapa pentingnya perencanaan SDM bagi Perusahaan

1. Kebutuhan Akan SDM Yang KompetenTerpenuhi Denganperencanaan SDM yang baik, the right men in the right placeakandapatdiraiholehperusahaan.

Penempatanpegawai yang kompetendantepatpadaposisinyadapatter capaidenganlebih optimal dancepatkarenaperusahaantelahmenget ahuidenganbaikkualitas SDM yang diperlukan.

2. Meningkatkan Efektivitas dan Efisiensi Perusahaan

BilajumlahSumberDayaManusia di dalamperusahaantelahtidakefisiendanefe ktiflagi, makasistemperencanaan SDM akanmelakukanpengaturanataupenempa tanulang. Tujuannyatentu agar semua SDM yang dimiliki bekerjapadajabatanataupekerjaanyang sesuaidengankemampuannya.Kalauhalit ubisadiraihmakaakanmampumemberikan kontribusi

maksimaldalampencapaiantujuandansas aranperusahaan.

3. Dapat Menghemat Biaya

Sebelummelakukanrekrutmen

alias mencaritenagakerjabaru, pihak HR terlebihdulumelakukanperombakan di dalam SDM.Misalnya, denganmelaksanakanpromosidanpemind ahanjabatan, mempensiunkan, ataubahkanmemberhentikanpekerja.Tent unyaharussesuaiperaturanketenaga-

kerjaan yang

berlaku.Denganmelakukanperombakante rlebihdahulu, makabiaya- biaya yang berhubungandenganpengadaantenagake rjadapatdihemat.

Apabilapenempatanulangdilakuka ndengantepat,

tidakakanterjadipenempatan yang keliru. Yang paling penting, tidakperlumenyediakanbiayamenambah SDM baru.Namundalambeberapakasus, penambahankaryawanbarumemangtidak dapatdihindari.Misalnya,

kantomembukacabangbaruatauusahabar u.

\section{- Manfaat Perencanaan}

1. meningkatkan sistem informasi SDM, yang secara terus menerus diperlukan dalam mendaya gunakan SDM secara efektif dan efisien bagi pencapaian tujuan bisnis perusahaan.

2. meningkatkan pendayagunaan SDM.

3. menyelaraskan aktivitas SDM dengan sasaran organisasi secara lebih efisien.

4. menghemat tenaga, waktu, dan dana serta dapat meningkatkan kecermatan dalam proses penerimaan tenaga kerja.

5. mempermudah pelaksanaan koordinasi dan pengelolahan SDM.

\section{- Sifat Perencanaan Sumber Daya Manusia}

Perencanaan SDM merupakan proses pengambilan keputusan dengan memperhatikan kemahiran dan pemanfaatan SDM, hal ini sebagai bagian dari proses penentuan keputusan strategis. Perencanaan SDM berfokus pada analisis tujuan perusahaan. Sementara perencanaan membutuhkan 
sumber daya untuk memenuhi tujuan tersebut. Tujuan perusahan dan kebutuhan sumber daya dianalisis dalam kaitannya dengan peran SDM dalam mencapai sasaran perusahaan.

Perencanaan SDM merupakan jumlah dari seluruh rencana yang diformulasi untuk rekrutmen, skrining, kompensasi, pelatihan, struktur pekerjaan, promosi, dan aturan main dari SDM perusahaan.

Permasalahan aspek perubahan keahlian dan keterbatasan personil yang mempengaruhi perencanaan SDM suatu perusahaan meliputi sebagai berikut.

1. Lemahnya arah program pendidikan nasional yang kurang berorientasi pada kebutuhan pasar .

2. Tingkat pengetahuan dan keahlian lulusan banyak yang belum memadai.

3. Perusahaan mengalami kekurangan tenaga ahli perencanaan SDM.

4. Pasar kerja mengalami kelebihan suplay karena sedang krisis ekonomi.

\section{- Teknik Perkiraan Kebutuhan SDM}

Teknik perkiraan kebutuhan SDM meliputi perkiraan jangka pendek dan jangka panjang. Yakni:

1. Teknik perkiraan jangka pendek

Teknik perkiraan jangka pendek akan kebutuhan SDM didasarkan pada pertimbangan kebijakan perusahaan akan anggaran dan beban kerja serta analisis struktur perusahaan.

a. Analisis anggaran

Di kebanyakan perusahaan, perkiraan kebutuhan SDM dicapai dengan proses penganggaran. Besar kecilnya anggaran menentukan berapa jumlah, tipe, dan kualitas karyawan yang diperlukan.

b. Analisis beban kerja

Beban kerja seseorang sudah ditentukan dalam bentuk standar kerja perusahaan menurut jenis pekerjaannya. Apabila sebagian karyawan bekerja sesuai dengan standar perusahaan tidak menjadi masalah. Sebaliknya, jika bekeraj di bawah standar mungkin karena beban kerja yang berlebih, sementara jika di atas standar, setiap peneyelia perbaikan mesin dan dua klerk penjualan pada setiap kemungkinan yang terjadi adalah memberikan estimasi standar yang rendah disbanding kapasitas karyawan itu sendiri.

c. Analisi struktur perusahaan

Struktur dalam perusahaan bisa berbentuk ramping dan gemuk. Jika struktur perusahaan disetiap lini lebih menggunakan teknologi padat modal, maka akan semakin ramping struktur perusahaan yang terjadi. Tetapi, jika struktur perusahaan enggunakan teknologi padat karya, maka akanmenjadi gemuk struktur perusahaan yang akan terjadi.

2. Teknik perkiraan jangka panjang

Teknik perkiraan jangka panjang terdiri atas analisis permintaan unit dan permintaan keorganisasian, pendapat pakar, analisis kecenderungan, analisis statistic, estimasi suplai internal, dan peramalan agregat.

a. Analisis permintaan unit Analisis permintaan unit merupakan bawah-atas. Disini, para penyelia diberi wewenang untuk memperkirakan jumlah karyawan yang dibutuhkan ditiap unitnya untuk periode tertentu. Perkiran tersebut dibawa ke atasan (manajer),

b. Analisis keorganisasian Teknik

permintaan permintaan keorganisasian merupakan pendekatan atas-bawah. Manajemen puncak membuat keputusan-keputusan tentang jumlah karyawan yang dibutuhkan di masa datang menurut berbagai kategori pekerjaan, posisi,, dan jabatan setiap karyawan.

c. Pendapat Pakar/ahli

Para pakar/ahli sangat dibutuhkan perusahaan untuk memperkirakan kebutuhan SDM manakala perusahaan tidak memiliki personalia yang kualifaid.

d. Analisis kecenderungan

Dua teknik perkiraan kebutuhan SDM yang paling sederhana adalah ekstrapolasi dan indeksasi. Teknik ekstrapolasi mendasarkan pada tingkat perubahan masa lalu. Semantara teknik indeksasi menandai tingkat perkembangan karyawan dengan menggunakan indeks.

e. Analisis statistic 


\begin{abstract}
Analisis menggunakan hasil simulasi uji statistic dengan mempertimbangkan kemungkinan terjadinya perubahan-perubahan internal dan eksternal perusahaan.
\end{abstract}

f. Analisis bagan penempatan

Bagan penempatan adalah suatu penyajian visual siapa yang akan menggantikan siapa dalam peristiwa pengisian lowongan jabatan, informasi untuk penyusunan berasal dari inventarisasi atau system sumber daya manusia. Didalam bagan tidak terdapat data tentang semua karyawan. Jadi, terutama hanya yang berkaitan dengan tenaga personalia teknis, professional, dan manajerial.

\section{- Peramalan Kebutuhan Sumber Daya Manusia}

Menurut Drs. Malayu S.P.Hasibuan ( 2012: 252) "Perencanaa SDM yang baik adalah jika ia dapat meramalkan masa depan dengan cara memproyeksikan hasil analisis informasi yang diperolehnya. Peramalan biasanya untuk masa 5 tahun yang akan datang".

Menurut Veithzal Rivai, (2013:32), "peramalan adalah faktor yang sangat penting dalam rangka mengantisipasi perubahan staf dan keperluan perusahaan". apabila ramalanramalannya mendekati kebenaran, rencana itu baik dan benar, karena ia dapat membaca situasi masa yang akan datang dengan baik.

MenurutSEDARMAYANTI, (2007:132). "Peramalan (forecasting) menggunakan informasi masa lalu dan saat ini untuk mengidentifikasi kondisi masa depan yang diharapkan. Proyeksi untuk masa yang akan datang tentu saja ada unsur ketidaktepatan. Basanya orang yang berpengalaman mampu meramal cukup akurat terhadap benefit organisasi dalam rencana jangka panjang".

Pendekatan-pendekatan untuk meramal SDM dapat dimulai dari perkiraan terbaik dari para manajer sampai pada simulasi komputer yang rumit. Asumsi yang sederhana mungkin cukup untuk jarak tertentu, tetapi jarak yang rumit akan diperlukan untuk yang lain.Jangka waktu peramalanPeramalan SDM harus dilakukan melalui tiga tahap: perencanaan jangka pendek, menengah dan panjang.Peramalan terhadap kebutuhan SDM (permintaan)

Penekanan utama dari peramalan SDM saat ini adalah meramalkan kebutuhan SDM organisasi atau permintaan kebutuhan akan SDM. Ramalan permintaan dapat berupa penilaian subjektif atau matematis.

- Tujuan Peramalan Antara lain :

1. Meramalkan kebutuhan dan persediaan tenaga kerja yang ada.

2. Meramalkan kemajuan pendidikan dan peningkatan kemampuan SDM.

3. Meramalkan kebutuhan akan jenis-jenis kecakapan yang berlainan dan jenis SDM (priawanita) pada masa yang akan datang.

Dalam

pengembangannya, organisasi akan membutuhkan sumber daya manusia yang sesuai, baik jumlah maupun kualitasnya. Peramalan kebutuhan sumber daya manusia akan membantu manajer dalam menentukan jumlah dan jenis kebutuhan tenaga kerja di masa yang akan datang. Hasilnya akan dijadikan dasar untuk penarikan karyawan baru. Penarikan dilakukan sesuai dengan kebutuhan sumber daya manusia, karyawan baru yang akan ditarik harus juga sesuai dengan kualitas yang dibutuhkan. Jenis sumber daya manusia yang dimiliki perusahaan akan menentukan hasil pekerjaan, sehingga akan berpengaruh pada produktivitas perusahaan.

\section{- Metode-Metode Meramalkan Kebutuhan Sumber Daya Manusia}

1. Trend analysis (analisis perkembangan)

Metode ini merupakan peramalan kebutuhan akan sumber daya manusia yang dilakukan secara logis dengan melakukan pengkajian berdasarkan kejadian-kejadian pada masa lampau. Dapat juga dilakukan untuk jenis pekerjaan kelompok baik untk pekerjaan pada bagian produksi maupun administrasi. Tujuannya adalah untuk dapat mengidentifikasi perkembangan jumlah kebutuhan sumber daya manusia di masa depan. 
2. Zero-Base (peramalan berbasis nol)

Metode ini menggunakan jumlah karyawan untuk menentukan kebutuhan sumber daya manusia di masa yang akan datang. Apabila suatu pekerjaan tertentu mengalami kekosongan akibat ditinggalkan pekerjanya tidak mempersoalkan karena pensiun, dipecat atau mengundurkan diri, kekosongan itu tidak diisi secara langsung. Tetapi terlebih dahulu dilakukan analisis yang secara cermat apakah perlu dilakukan pengisian karyawan baru sebagai pengganti atau tidak. Suatu kemungkinan dapat dilakukan dengan melatih karyawan yang bertahan untuk dapat mengerjakan pekerjaan yang kosong tersebut.

3. Bottom-Up Approach (pendekatan dari bawah ke atas)

Kebutuhan akan sumber daya manusia dapat ditentukan melalui peramalan pada setiap tingkatan setiap bagian secara berurutan mulai tingkatan yang terendah sampai tertinggi. Pendektan ini didasarkan bahwa manajer pada setiap bagian dalam perusahaan dapat meramalkan kebutuhan akan sumber daya manusia.

Begitu pula pada setiap bagian organisasi mulai dari tingkat rendah sampai tertinggi dapat menentukan kebutuhan akan sumber daya manusia, pada akhirnya akan diperoleh jumlah secara keseluruhan. Proses ini lebih bersifat interaktif karena selalu ada diskusi dan negosiasi dalam peramalan kebutuhan pada bagian tingkat rendah dengan tingkat diatasnya, begitu seterusnya sampai ketingkat paing atas.

4. Ratio Analysis (analisis ratio)

Pendekatan ini menentukan perbandingan antara jumlah pekerjaan dengan jumlah sumber daya manusia yang dibutuhkan. Sebagai contoh, misalnya sepuluhn orang karyawan dapat menyelesaikan lima puluh pekerjaan dalam waktu seminggu, bila perusahaan ada pesanan lima ratus pekerjaan untuk diselesaikan satu minggu maka perusahaan akan membutuhkan sepuluh tenaga kerja. Seorang tenaga penjual dapat menghasilkan 50 juta rupiah sebulan, sehingga dibutuhkan 10 tenaga kerja untuk menghasilkan 500 juta rupiah. Apabila perusahaan merencanakan jumlah penjualan 700 juta pada bulan berikutnya, maka akan dibutuhkan sebanyak 14 tenaga penjual.

5. Correlation Analysis (analisis korelasi)

Analisis korelasi merupakan suatu metode analisis statistik yang bertujuan untuk menegtahui hunungan antar dua variabel, misalnya antara volume penjualan dengan jumlah kebutuhan karyawan. Para manajer dapat meramalkan jumlah kebutuhan sumber daya manusia di masa yang akan datang dengan menggunakan metode analisis korelasi. Analisis korelasi memberikan hasil yang lebih akurat untuk meramalkan jumlah kebutuhan sumber daya manusia dibandingkan dengan analisis perkembangan dan analisis rasio.

\section{- TEKNIK PERAMALAN}

$\begin{array}{lrr}\text { Teknik } & \text { peramalan } & \text { (forecasting) } \\ \text { merupakan } & \text { instrumen } & \text { suatu } \\ \text { perencanaan. } & \text { Sedarmayanti,(2007:133). } \\ \text { "Menyatakan } & \text { upaya } & \text { untuk }\end{array}$ memperkirakan kebutuhan SDM dimasa mendatang dapat dilakukan dengan teknik forecasting".

Beberapa teknik forecasting yang dapat digunakan dalam melakukan peramalan berkaitan dengan penyusunan perencanaan SDM, seperti : a. Teknik Delphi

Teknik ini menggunakan keahlian sekelompok orang (biasanya manajer). Para perencana di departemen SDM dalam hal ini berfungsi sebagai penengah, menyimpulkan berbagai pendapat dan melaporkan kesimpulankesimpulan dari pendapat-pendapat sekelompok orang tersebut kepada para ahli. Laporan ini kemudian dikaji ulang dengan cara mensurvei ulang. Kegiatankegiatan ini diulang sampai para ahli mencapai consensus (biasanya empat sampai lima kali survei sudah cukup).

b. Ekstrapolasi

Teknik ekstrapolasi ini mendasarkan diri pada tingkat perubahan atau kecenderungan pada masa lalu untuk membuat proyeksi dimasa yang akan datang. Penggunaan 
teknik ekstrapolasi berangkat dari pemikiran bahwa kehidupan organisasi merupakan suatu yang berulang (kontinum). Teknik ini akan mempunyai keabsahan (Validitasi) yang tinggi bila menggunakan asumsi Cateris Paribus. Artinya faktor-faktor lain diasumsikan tidak berubah merupakan kelemahan dari teknik ini. Pada kenyataannya kondisi atau lingkungan selalu berubah. Dengan demikian teknik ini hanya dapat digunakan untuk perencanaan SDM jangka pendek. Sedangkan perencanaan SDM jangka panjang, teknik ini tidak berlaku.

Contoh teknik ekstrapolasi : Bila rata-rata dua karyawan diterima setiap bulan dibagian produksi selama dua tahun yang lalu, maka berarti ada 24 karyawan yang akan diterima oleh bagian produksi untuk satu tahun mendatang. Asumsi teknik ini adalah, penyebab permintaan sama dari waktu ke waktu.

c. Indeksasi

Indeksasi adalah teknik estimasi kebutuhan SDM di masa yang akan datang dengan menandai tingkat perkembangan karyawan dengan indeks. Teknik indeksasi berangkat dari asumsi bahwa faktor-faktor yang mempengaruhi permintaan atas tenaga kerja baik yang bersifat eksternal maupun internal berada pada kondisi konstan. Sebagaimana halnya dengan teknik ekstrapolasi, teknik ini juga hanya berguna untuk perencanaan jangka panjang.

Contoh klasik teknik ini : rasio antara karyawan produksi dengan hasil penjualan. Sebagai contoh, para perencana bisa menyimpulkan bahwa setiap sepuluh juta rupiah kenaikan penjualan, departemen produksi memerlukan satu tambahan karyawan baru. teknik ini mengasumsikan penyebab-penyebab permintaan tetap sama dari waktu ke waktu.

d. Analisis Statistik

Berbeda dengan teknik ekstrapolasi dan taknik indeksasi, teknik ini digunakan untuk perencanaan SDM jangka panjang. Teknik ini lebih rumit dari indeksasi maupun ekstrapolasi, namun hasilnya lebih akurat untuk jangka panjang karena teknik ini mempertimbangkan

bergesarnya tuntutan terhadap kebutuhan SDM. Analisis statistik yang dikenal umum adalah regresi dan korelasi.

\section{- Meramalkan Ketersediaan Sumber Daya Manusia}

1. Meramalkan ketersediaan dari luar perusahaan

Meramalkan ketersediaan sumber daya manusia bersumber dari luar perusahaan merupakan pertimbangan penting mengingat terbatasnya jumlah dan kualitas sumber daya manusia yang tersedia di dalam perusahaan. Berbagai faktor penting perlu diperhatikan, perkembangan jumlah penduduk, dan perkembangan-perkembangan dalam industri yang merupakan penentu ketersediaan sumber daya manusia.

\section{Melihat} perkembanganperkembangan dalam industri, pesatnya pertumbuhan industri secara nasional akan membutuhkan sumber daya manusia dalam jumlah besar. Keadaan ini berakibat pada semakin sulit mencari sumber daya manusia sesuai kebutuhan. Keadaan sebaliknya, lesunya pertumbuhan industri berdampak pada banyak perusahaan yang berhenti kegiatannya akan mengurangi jumlah sumber daya manusia yang dimiliki. kondisi ini berakibat pada banyak karyawan yang berhenti bekerja, menimbulkan bertambahnya ketersediaan sumber daya manusia.

2. Meramalkan ketersediaan dari dalam perusahaan

Peramalan ketersediaan sumber daya manusia yang bersumber dari dalan perusahaan akan mempertimbangkan karyawan yang pindah pekerjaan ke pekerjaan lain akibat promosi, mutasi, demosi, pensiun, dan keluar dari perusahaan.

Melakukan identifikasi sumber daya manusia yang ada sekarang perlu memperhitungkan jumlah yang keluar pada suatu periode tertentu, seperti promosi, mutasi, demosi, pensiun. Kemudian dilakukan penambahan sumber daya manusia sesuai kebutuhan perusahaan pada periode tertentu, seperti penarikan dari dalam dan luar 
perusahaan. Mengindetifikasi sumber daya manusia yang tersedia sekarang dapat dilakukan melalui penelusuran data kepegawaian pada biro sumber daya manusia. Pada arsip kepegawaian akan diperoleh informasi tentang pendidikan, keterampilan, minat dan karir karyawan yang bersangkutan yang dijadikan sebagai dasar promosi jabatan, dan proses pemindahan pekerjaan lainnya. Berkaitan dengan hal tersebut dapat dijadikan dasar untuk peramalan sumber daya manusia dimasa mendatang.

\section{- Faktor-Faktor Yang Mempengaruhi Peramalan (Forcasting) \\ Ada tiga faktor yang} mempengaruhi untuk dilakukannya forecast SDM bagi perusahaan adalah;

\section{Faktor Eksternal}

Persediayaan karyawan berdasarkan analisa pasar tenaga kerja serta tren kondisi kependudukan sehingga ada kerjasama antara penyedia tenaga kerja denga perusahaan dengan menjamin kuantitas dan kualitas karyawan.

$\checkmark$ Faktor ekonomi nasional dan industri : faktor ini secara langsung berpengaruh rencana strategi (taktik) sebuah organisasi.

$\checkmark$ faktor sosial politik dan hukum: faktor- faktor ini tidak boleh diabaikan dalam sebuah organisasi termasuk juga dalam melakukan perencanaan SDM, faktor ini yang menempatkan penguasaan bahasa asing, khususnya bahasa inggris yang semakin penting dalam bekomunikasi telah mengharuskan organisasi menjadikan sebagai pertimbangan yang besar pengaruhnya dalam perencanaan SDM.

$\checkmark$ Faktor teknologi: perkembangan dan kemjuan ilmu pengetahuan yang pesat telah diiringi pula dengan dihasilkannya teknologi baru, baik yang berhubungan dengan cara kerja dan peralatan untuk meningkatkan produktifitas dan kualitasnya baik untuk memenuhi keinginan dan kebutuhan konsumen yang juga terus meningkat kualitasnya.

$\checkmark$ Faktor pesaing : faktor pesaing merupakan wujud dari tantangan yang semakin berat dalam dunia bisnis, bagi suatu organisasi akan mempengaruhi pasar bagi produknya baik berupa barang atau jasa, untuk merebut dan memenangkan sebuah organisasi

\section{Faktor Internal} diperlukan SDM yang kompetitif.

Menghitung jumlah para karyawan serta mengevaluasi kemampuan mereka sebagai bentuk adanya kemungkinan untuk penugasan para karyawan untuk mengisisi lowongan - lowongan pekerjaan yang akan datang.

$\checkmark$ Rencana strategik dan rencana operasional (taktik): rencana ini tidak mungkin terwujud tanpa SDM yang relevan dan kompetitif, maksudnya suatu organisasi harus mempunyai keahlian dalam organisasinya sehingga mampu menghasilkan produk secara berkualitas .

1. Anggaran (cost) SDM dilingkungan organisasi perusahaan yang disebut pekerjaan (karyawan) adalah orang yang digaji (diupah).

2. Peramalan (prediksi) produksi dan penjualantidak bisa oleh dilakukan secara spekulatif, tetapi harus didasarkan pada data sebelumnya dan survey pasar agar dapat dilakukan perhitungan yang obyektif.

$\checkmark$ Faktor bisnis baru : Dengan memperhatikan lingkungan dan kemampuan, menganalisis, dan memanfaatkan informasi selalu tebuka peluang bagi organisasi.

$\checkmark$ Faktor desain organisasi dan desain pekerjaan : Dirancang untuk mewujudkan pekerjaan agar berlangsung efektif dan efisien.

$\checkmark$ Faktor keterbukaan : Manajer yang terbukadengan memberikan informasi yang lengkapuntuk melakukan analisis tenaga kerja maka akan memberikan peluang 
dihasilkannya perencanaan yang akurat.

\section{Faktor Ketenagakerjaan}

Adalah untuk meningkatkan kecermatan dalam menyusun perencanaan tenaga kerja atau SDM kedepan.

1. Pensiun, PHK, Meninggal dunia, dan karyawan yang sering absen, sehingga tidak luput dari prediksi manajemen SDM dan harus ada penggantinya

2. Promosi ( kenaikan pangkat), pindah, dan kaeryawan yang mendapat tugas pelatihan diluarjuga harus diperhitungkan, baik dengan cara pergantian maupun rancangan penempatanyang lebih tepat.

\section{- Komitmen}

Dalam sebuah perusahaan tentu karyawan dituntut untuk dapat memberikan kinerja terbaik pada perusahaan sesuai dengan kompetensi yang dimilikinya. Tetapi kompetensi saja tidak cukup agar karyawan dapat memberikan kinerja terbaiknya dalam pekerjaannya.

Selain kompetensi, komitmen kerja bagi karyawan, dosen, guru, pegawai ataupun pekerja juga diperlukan agar mereka memberikan hasil terbaik bagi organisasi atau perusahaan.

Seseorang yang tidak memiliki komitmen, sebenarnya ia ahli dalam bidangnya (competent) namun ia bekerja dengan setengah hati. Karyawan yang memiliki suatu komitmen, akan bekerja secara total, mencurahkan perhatian, pikiran, tenaga dan waktunya, ia mengerjakan apa yang diharapkan oleh perusahaan.

Komitmen organisasi adalah loyalitas karyawan terhadap organisasi melalui penerimaan sasaran-sasaran, nilai-nilai organisasi, kesediaan atau kemauan untuk berusaha menjadi bagian dari organisasi, serta keinginan untuk bertahan di dalam organisasi.

Greenberg dan Baron (2000:82) "Mengemukakan bahwa komitmen kerja merefleksikan tingkat identifikasi dan keterlibatan individu dalam pekerjaannya dan ketidaksediaannya untuk meninggalkan pekerjaan tersebut".
Dari beberapa pengertian di atas jelas bahwa komitmen merupakan bagian yang terkait dengan kinerja karyawan dalam hubungannya dengan pekerjaannya.

Dalam sebuah komitmen juga memiliki unsur atau komponen yang saling berhubungan. Ketika semua komponen terpenuhi maka semakin besar komitmen karyawan dalam pekerjaannya. Komitmen organisasi terdiri dari 3 komponen yaitu: 1. Komitmen kerja afektif (affective occupational commitment)

Komitmen sebagai ketertarikan afektif/psikologis karyawan terhadap pekerjaannya. Komitmen ini menyebabkan karyawan bertahan pada suatu pekerjaan karenamereka menginginkannya.

2. Komitmen kerja kontinuans (continuance occupational commitment)

Mengarah pada perhitungan untung-rugi dalam diri karyawan sehubungan dengan keinginannya untuk tetap mempertahankan atau meninggalkan pekerjaannya. Artinya, komitmen kerja disini dianggap sebagai persepsi harga yang harus dibayar jika karyawan meninggalkan pekerjaannya. Komitmen ini menyebabkan karyawan bertahan pada suatu pekerjaan karena mereka membutuhkannya. 3. Komitmen kerja normatif (normative occupational commitment)

Komitmen sebagai kewajiban untuk bertahan dalam pekerjaannya. Komitmen ini menyebabkan karyawan bertahan pada suatu pekerjaan karena mereka merasa wajib untuk melakukannya serta didasari pada adanya keyakinan dan kesetiaan pada organisasi.

Tidak semua komponen di atas dimiliki oleh karyawan, tetapi lebih baik lagi jika ketiga komponen tersebut dimiliki oleh karyawan. Sebagai contoh, ketika komponen affective occupational commitment lebih dominan maka karyawan tersebut merasa lebih cocok dengan bidang pekerjaannya, baik itu secara emosional maupun kesesuaian antara karakteristik pekerjaan dengan dirinya. 
la merasa bahwa pekerjaannya sesuai dengan bidang pendidikannya, hobinya, tujuannya, kebersamaan, kenyamanan dan lain-lain. Tetapi jika karyawan tidak pernah diberikan pengembangan pengetahuan dan skill melalui seminar, training dll. Maka dapat menimbulkan kurangnya komponen normative occupational commitment dan dapat juga mempengaruhi kinerja dibandingkan dengan karyawan yang memiliki tingkat komitmen yang setara.

- Bentuk-Bentuk Komitmen Organisasi Allen dan meyer dalam bukunya Greenberg \& Baron, (2000:135), "mendefinisikan komitmen perusahaan sebagai sebuah konsep yang memiliki tiga dimensi(bentuk) yaitu affective, normatif, dan continuance commitment. Affective commitment adalah tingkat seberapa jauh seorang pegawai secara emosional terikat, mengenal, dan terlibat dalam organisasi. Continuance commitment adalah suatu penilaian terhadap biaya yang terkait dengan meninggalkan organisasi. Normative commitment merujuk kepada tingkat seberapa jauh seseorangsecara psikologi terikat untuk menjadi pegawai dari sebuah organisasi yang didasarkan kepada perasaan seperti kesetiaan, afeksi, kehangatan, kepemilikan, kebanggaan, kesenangan, kebahagiaan, dan lain-lain".

Menurut Greenberg \& Baron (2000:182), bentuk-bentuk komitmen organisasi adalah:

a. Affective Commitment ialah kuatnya keinginan seseorang dalam bekerja bagi organisasi atau perusahaan disebabkan karena dia setuju dengan tujuantujuan perusahaan tersebut dan ingin melakkannya.

b. Continuance Commitmentaialah kuatnya keinginan seseorang dalam melanjutkan pekerjaannya bagi perusahaan disebabkan karena dia membutuhkan pekerjaan tersebut dan tidak dapat melakukan pekerjaan yang lain.

c. Normative Commitment ialah kuatnya keinginan seseorang dalam melanjutkan pekerjaannya bagi perusahaan disebabkan karena dia merasa berkewajiban dari orang lain untuk dipertahankan.

Setiap karyawan memiliki dasar dan tingkah laku yang berbeda berdasarkan komitmen perusahaan yang dimilikinya. Karyawan yang memiliki komitmen perusahaan dengan dasar eektif memiliki tingkah laku berbeda dengan karyawan yang berdasarkan continuance. Karyawan yang ingin menjadi anggota akan memiliki keinginan untuknmenggunakan usaha yang sesuai dengan tujuan perusahaan, sebaliknya, mereka yang terpaksa menjadi anggota akan menghindari kerugian finansial dan kerugian lainnya, sehingga mungkin hanya melakukan yang tidak maksimal.

Sementara itu, komponen normatif yang berkembang sebagai hasil dari pengalaman sosialisasi, tergantung dari sejauh apa perasaan kewajiban yang dimiliki karyawan. Komponen normatif menimbulkan perasaan kewajiban pada pegawai untuk memberi balasan atas apa yang telah diterimanya dari perusahaan.

\section{- Konsekuensi Dari Komitmen Perusahaan}

Menurut greenbeg dan baron(2000:184), konsekuensi dari komitmen yaitu:

a. commited employees areless likelyto withdraw

pegawai yang memiliki komitmen mempunyai kemungkinan lebih kecil untuk mengundurkan diri. Semakin besar komitmen karyawan pada perusahaan, maka semakin kecil kemungkinan untuk mengundurkan diri. Komitmen mendorong orang untuk tetap mencintai pekerjaannya dan akan bangga ketika dia sedang berada disana.

b. Commited employees are less willing to saorifice for the organitation

Pegawai yang memiliki komitmen bersedia untuk berkorban demi perusahaannya. Karyawan yan memiliki komitmen menunjukkan kesadaran tinggi untuk membagikan dan berkorban yang 
diperlukan untuk kelangsungan instansi.

\section{- Faktor-Faktor Yang Memepengaruhi Komitmen Karyawan}

Ada tiga faktor yang mempengaruhi komitmen karyawan, yaitu: karakteristik pribadi (kebutuhan berprestasi, masa kerja/jabatan), kaakteristik pekerjaan (umpan balik, identitas tugas, kesempatan untuk brinteraksi) dan pengalaman kerja.

Menurut armstong (2005:183) “ berpendapat bahwa tiga hal hal yang dapat mempengaruhi komitmen yaitu: rasa memiliki terhadap perusahaan, rasa senang terhadap pekerjaan dan kepercayaan pada perusahaan" Sedangkan Menurut long dalam bukunya armstrong (2005:184), "program kepemilikan saham perusahaan bagi karyawan juga bisa menumbuhkan perasaan identifikasi terhadap tujuantujuan perusahaan".

Dari beberapa uraian teoritis diatas, peneliti mengambil kesimpulanmengenai faktor-faktor yang mempengaruhi komitmen perusahaan bahwa komitmen perusahaann sebagai rasa identifikasi, keerlibatan, loyalitas yang dinyatakan oleh seorang karyawan terhadap perusahaannya. Dimana identifikasi yaitu penerimaan tujuan perusahaan, dimana penerimaan ini merupakan dasar komitmen perusahaan. Keterlibatan yaitu sesuai dengan peran dan tanggung jawab pekerjaan di perusahaan tersebut. Karyawan yang memiliki komitmen tinggi akan menerima hampir semua tugas dan tanggung jawab pekerjaan yang diberikan.

Loyalitas yaitu kesediaan seseorang untuk melanggengkan hubungannya dengan perusahaan, kalau perlu dengan mengorbankan kepentingan pribadinya tanpa mengharapkan apapun.

\section{- Jenis-Jenis Komitmen Karyawan}

1. Komponen afektif

Berkaitan dengan emosional, identifikasi, dan keterlibatan pegawai di dalam suatu organisasi. Pegawai dengan afektif tinggi masih bergabung dengan organisasi karena keinginan untuk tetap menjadi anggota organisasi.

2. Komponen normatif
Merupakan perasaan pegawai tentang kewajiban yang harus diberikan kepada organisasi. Komponen normatif berkembang sebagai hasil dari pengalaman sosialisasi, tergantung dari sejauh apa perasaan kewajiban yang dimiliki pegawai. Komponen normatif menimbulkan perasaan kewajiban kepada pegawai untuk memberikan balasan atas apa yang pernah diterimanya dari organisasi. 3. Komponen continuance berarti komponen yang berdasarkan persepsi pegawai tentang kerugian yang akan dihadapinya jika meninggalkan organisasi. Pegawai dengan dasar organisasi tersebut disebabkan karena pegawai tersebut membutuhkan organisasi. Pegawai yang memiliki komitmen organisasi

Dengan dasar afektif memiliki tingkah laku yang berbeda dengan pegawai dengan dasar continuance. Pegawai yang ingin menjadi anggota akan memiliki keinginan untuk berusaha yang sesuai dengan tujuan organisasi. Sebaliknya pegawai yang terpaksa menjadi anggota organisasi akan menghindari kerugian financial dan kerugian lain, sehingga mungkin hanya melakukan usaha yang tidak maksimal. komitmen karyawan dikenal sebagai pendekatan sikap terhadap organisasi.

Komitmen karyawan memiliki dua komponen yaitu sikap dan kehendak untuk bertingkah laku. Sikap mencakup identifikasi dengan organisasi yaitu penerimaan tujuan organisasi, di mana penerimaan ini merupakan dasar komitmen karyawan. Identifikasi pegawai tampak melalui sikap menyetujui kebijaksanaan organisasi, kesamaan nilai pribadi dan nilai-nilai organisasi, rasa kebanggaan menjadi bagian dari organisasi. Sikap juga mencakup keterlibatan seseorang sesuai peran dan tanggungjawab pekerjaan di organisasi tersebut. Pegawai yang memiliki komitmen tinggi akan menerima hampir semua tugas dan tanggungjawab pekerjaan yang diberikan padanya.

Selain itu sikap juga mencakup kehangatan, afeksi, dan loyalitas terhadap organisasi merupakan evaluasi dari komitmen, serta adanya ikatan 
emosional dan keterikatan antara organisasi dengan pegawai. Pegawai dengan komitmen tinggi merasakan adanya loyalitas dan rasa memiliki terhadap organisasi.

Sedangkan yang termasuk kehendak untuk bertingkah laku adalah kesediaan untuk menampilkan usaha.

Hal ini tampak melalui kesediaan bekerja melebihi apa yang diharapkan agar organisasi dapat maju. Pegawai dengan komitmen tinggi, ikut memperhatikan nasib organisasi. Keinginan juga termasuk kehendak untuk tetap berada dalam organisasi. Pada pegawai yang memiliki komitmen tinggi, hanya sedikit alasan untuk keluar dari organisasi dan berkeinginan untuk bergabung dengan organisasi yang telah dipilihnya dalam waktu lama.

Jadi seseorang yang memiliki komitmen tinggi akan memiliki identifikasi terhadap organisasi, terlibat sungguhsungguh dalam pegawai dan ada loyalitas serta afeksi positif terhadap organisasi. Selain itu tampil tingkah laku yang berusaha ke arah tujuan organisasi dan keinginan untuk tetap bergabung dengan organisasi dalam jangka waktu lama.

\section{METODOLOGI PENELITIAN - Lokasi Penelitian}

Adapun lokasi penelitian untuk mengetahui pengaruh perencanaan dan peramalan untuk membangun komitmen karyawan PT.BPRS SARANA PRIMA MANDIRI pamekasan yaitu di Jl.Agus Salim 20 pamekasan.

- Jenis Penelitian

Jenis penelitian ini merupakan penelitian asosiatif atau hubungan. Menurut sugiyono (2006: 11-12) "penelitian asosiatif merupakan penelitian yang bertujuan untuk mengetahui hubungan antara dua variabel atau lebih". Dengan penelitian ini maka akan dapat dibangun suatu teori yang dapat berfungsi untuk menjelaskan, meramalkan dan mengontrol suatu gejala.

\section{- Populasi dan Sampel}

Menurut pendapat sugiono (2006:57) menyebutkan "bahwa populasi adalah wilayah generaliasi yang terdiri atas obyek/subyek yang mempunyai kuantitas dan karaktristik tertentu yang di tetapkan peneliti untuk dipelajari dan kemudian di tarik kesimpulan". Yang menjadi respon penelitian ini adalah semua karyawan PT.BPRS SARANA PRIMA MANDIRI pamekasan yang berstatus pegawai tetap.

Menurut sugiono (2006:57) menyatakan "bahwa sebagian dari jumlah dan karakteristik yang dimiliki oleh populasi tersebut". Penelitian ini adalah penelitian

populasi, dimana peneliti memberikan angket kepada semua karyawan PT.BPRS SARANA PRIMA MANDIRI pamekasan yang berjumlah 43 karyawan kecuali pemimpin.

- Definisi Operasional Dan Identifikasi Variabel Definisi Operasional Variabel

Menurut sugiono $(2001 ; 21)$ menyatakan "bahwa variabel independen atau bebas adalah variabel yang menjadi sebab perubahannya atau timbulnya variabel independen".selanjutnya sugiono (2001:21) menyatakan "bahwa varibel independen adalah variabel yang di pengaruhi atau yang menjadi akibat karena adanya variabel bebas".

Dari pendapat tersebut di atas, maka definisi operasional variabel dalam penelitian ini adalah:

a. Variabel bebas yaitu perencanaan $(\mathrm{X} 1)$ dan peramalan (X2):

1. Perencanaan (X1) diartikan sebagai proses untuk memutuskan tujuan-tujuan yang akan dicapai selama periode mendatang dan aktivitas-aktivitas yang harus dilakukan agar dapat mencapai tujuan tersebut.

2. Peramalan (X2) diartikan sebagai meramalkan kebutuhan tenaga kerja beberapa tahun kedepan sesuai dengan rencana bisnis dan rencana strategis perusahaan, dan memberikan dasar bagi pelaksanaan rekruetment, seleksi, penempatan, pelatihan, dan pengembangan karyawan, perencanaan dan pengembangan karir serta PHK. 
b. Variabel terikat (Y) yaitu komitmen karyawan merupakan suatu tugas dan tanggung jawab yang dimiliki karyawan untuk bekerja dengan baik kepada perusahaan untuk mencapai suatu tujuan karyawan.

Identifikasi Variabel

1. variabel bebas $(X)$ terdiri dari:

A. perencanaan (X1) dapat diukur dengan indikator:

a. Kebutuhan Akan SDM Yang KompetenTerpenuhi

b. Meningkatkan Efektivitas dan Efisiensi Perusahaan

c. Dapat Menghemat Biaya

B. Peramalan (X2) dapat diukur dengan indikator:

a. Meramalkan kebutuhan dan persediaan tenaga kerja yang ada.

b. Meramalkan kemajuan pendidikan dan peningkatan kemampuan SDM.

c. Meramalkan kebutuhan akan jenisjenis kecakapan yang berlainan dan jenis SDM (pria-wanita) pada asa yang akan datang.

2. variabel terikat $(\mathrm{Y})$ adalah komitmen karyawan yang diukur dengan indikator sebagai berikut:

a. keinginan untuk bertahan di dalam organisasi

b. kesetiaan dalam organisasi

c. keyakinan dan kesetiaan pada organisasi

\section{- Tehnik Pengumpulan Data}

Adapun prosedur pengumpulan data, pada penelitian ini adalah sebagai berikut:

a. Survei pendahuluan, berupa penelitian secara umum terhadap karyawan pt.bprs sarana prima mandiri pamekasan untuk mengetahui permasalahan yang dihadapi.

b. Penelitian lapangan, sebagai suatu upaya dengan melakukan survey terhadap obyek yang akan diteliti untuk memperoleh data primer secara langsung melalui:

\section{Wawancara}

Tehnik ini dilakukan dengan cara melakukan tanya jawab secara langsung kepada responde. Hal ini dilakukan untuk memperjelas terhadap pertanyaan yang dianggap kurang jelas oleh responden. Disamping itu tehnik ini juga untuk mengetahui secara lebih mendetail beberapa alasan responden memberikan penilaian tertentu terhadap pertanyaan yang diajukan.

\section{Kuesioner}

Tehnik dalam pengumpulan data yang di gunakan dalam penelitian ini digunakan cara menyebarkan angket kepada responden. Responden diminta untuk menanggapi dengan cara memberikan sikapnya terhadap variabel yang ada dengan menggunakan skala penilaian model likert dengan rentangan 1 sampai 5 untuk mengindikasikan jawaban sangat tidak setuju - sangat setuju . adapun skala penilaiannya adalah sebagai berikut:
a. Nilai 1 menunjukkan jawaban/pendapat sangat tidak setuju.
b. Nulai 2 menunjukkan jawaban/pendapat tidak setuju.
c. Nilai 3 menunjukkan jawaban/pendapat cukup setuju
d. Nilai 4 menunjukkan jawaban/pendapat setuju
e. Nilai 5 menunjukkan jawaban/pendapat sangat setuju

\section{Study Kepustakaan}

Tehnik ini dilakukan dengan cara mendapatkan sumber informasi dari berbagai literatur atau teori-teori yang mendukung dan yang berhubungan dengan materi penelitian.

\section{- Pengujian Instrument Data Uji Validitas}

Uji validitas data bertujuan untuk mengetahui sejah mana validitas data yang diperoleh dari penyebaran kuesioner. Uji validitas data dengan menggunakan metode korelasi productmoment (person correlation) (Sugiono,2002:277).

Data dikatakan valid apabila $r$ hitung lebih besar $(>)$ dari $r$ tabel. Selain itu juga bisa dilihat dari signifikansinya lebih besar dari 0,05 maka data tersebut dapat dikatakan tidak valid. Jika nilai 
signifikansinya lebih kecil dari 0,05 maka data tersebut dikatakan valid. Selain itu data dikatakan valid apabila memiliki koefisien korelasi > 300. Dengan demikian semua butir pertanyaan atau pernyataan tersebut dapat digunakan dan dapat dipercaya untuk mengumpulkan data yang diperlukan.

- Uji Reliabilitas

Pengujian keandalan alat ukur dalam penelitian ini menggunakan reliabilitas metode cronbach alpha (Danim, 2000:199).

\section{Teknik Analisa Dan Uji Hipotesis}

- Teknik Analisa

Teknik analisa dapat diperlukan untuk menguji kebenaran pembahasan dan menganalisa, adapun teknik penelitian ini terdiri dari dua analisis yaitu analisis kualitatif dan analisis yang bersifat kuantitatif.

\section{1) Analisa kualitatif}

Merupakan analisa yang memberikan gambaran tentang objek yang akan diteliti. Metode ini mengkaji variable-variabel yang ada pada penelitian adapun teknik ini menggunakan skala linkert sebagai berikut:

$\begin{array}{ll}> & = \\ & \text { Sangat Baik } \\ > & = \\ & \text { Baik } \mathrm{s} / \mathrm{d} 5,00 \\ & 3,51 \mathrm{~s} / \mathrm{d} 4,49 \\ & \text { Cukup Baik } \\ & 2,51 \mathrm{~s} / \mathrm{d} 3,49 \\ & = \\ & \text { Tidak Baik } \\ & 1,51 \mathrm{~s} / \mathrm{d} 2,49 \\ & \text { Sangat Tidak Baik } \\ & \end{array}$

\section{2) Analisa kuantitatif}

Suatu analisa dengan menggunakan perhitungan berdasarkan angka-angka dari olahan data yang didapat dengan tujuan untuk memberikan gambaran tentang kondisi obyek yang diteliti berdasarkan perhitungan statistic.

Adapun tehnik ini dengan menggunakan persamaan regresi linear berganda dengan rumus:

$$
\begin{array}{cl}
\mathrm{Y}=\mathrm{a}+\mathrm{b}_{1} \mathrm{X}_{1}+\mathrm{b}_{2} \mathrm{X}_{2}+\mathrm{e} \\
\text { Dimana: } \mathrm{Y} & =\text { Kinerja Karyawan } \\
\mathrm{a} & =\text { Bilangan konstanta } \\
\mathrm{b}_{1} \mathrm{~b}_{2} & =\text { Koefisien regresi }
\end{array}
$$

$\mathrm{X}_{1} \mathrm{X}_{2}=$ Variabel independent/ Variabel bebas

\section{- Uji Hipotesa}

\section{1) Uji T.}

Untuk membuktikan hipotesis ke dua maka digunakan uji $\mathrm{T}$ atau tes yaitu untuk mengetahui sumbangan dari masing-masing variabel bebas secara parsial terhadap variable terikat, dan untuk mencari nilai $t$ yang paling tinggi atau dominan dengan menggunakan rumus berdasarkan pendapat Sugiono $(2001 ; 154)$ adalah sebagai berikut.

Dengan membandingkan thitung dan $\mathrm{t}$ table pada 0,05 maka:

1. $t$ hitung $\leq \mathrm{t}$ tabel maka Ho diterima dan $\mathrm{Hi}$ ditolak, artinya variable bebas kurang menjelaskan variable terikat.

2. $\mathrm{t}$ hitung $\geq \mathrm{t}$ table maka Ho ditolak dan $\mathrm{Hi}$ diterima artinya variable bebasnya dapat menjelaskan variable terikatnya.

\section{2) Uji F}

Uji F digunakan untuk membuktikan hipotesis pertama yang merupakan pengujian secara simultan.

Menurut pendapat Sugiono (2001:154) menyatakan untuk menguji hipotesis komperatif lebih dari dua ratarata sampel digunakan tehnik statistik yang disebut analisis varians.

Dengan membandingkan $F$ hitung dengan $F$ tabel pada $\alpha 0,05$ dengan hasil perhitungan menunjukkan:

1. Apabila $F$ hitung $\geq F$ tabel maka $\mathrm{Hi}$ diterima oleh Ho ditolak

2. Apabila $F$ hitung $\leq F$ tabel maka Ho diterima oleh Hi ditolak.

\section{Pembahasan \\ Uji Validitas Dan Uji Reliabilitas Uji Validitas}

Uji validitas data bertujuan untuk mengetahui sejauh mana validitas data yang diperoleh dari penyebaran kueioner. Berdasarkan hasil perthitungan korelasi dari variabel semua faktor maka untuk mengetahui validitas dari semua variabel maka dilakukan uji validitas semua faktor yang akan diteliti. Variabel dinyatakan valid apabila koefisien $r>0,3$. Adapun hasil uji validitas adalah sebagai beriukut: 
Tabel Hasil Perhitungan Uji Validitas

\begin{tabular}{|c|c|c|c|c|}
\hline \multicolumn{2}{|r|}{ Indikator } & $r$ hitung & $r$ tabel & Keterangan \\
\hline $\begin{array}{l}\text { Variabel X } \\
\text { Item } 1 \\
\text { Item } 2 \\
\text { Item } 3 \\
\text { Item } 4 \\
\text { Item } 5 \\
\text { Item } 6\end{array}$ & $\begin{array}{l}\text { SDM yang kompeten tepenuhi } \\
\text { Efektivitas dan efisiensi perusahaan } \\
\text { Menghemat biaya } \\
\text { Persedian tenaga kerja } \\
\text { Kemajuan pendidikan dan } \\
\text { kemampuan SDM } \\
\text { Kebutuhan akan jenis-jenis } \\
\text { kecakapan yang belainan jenis } \\
\text { masa yang akan datang }\end{array}$ & $\begin{array}{l}0,639 \\
0,379 \\
0,399 \\
0,527 \\
0,804 \\
0,689\end{array}$ & $\begin{array}{l}0,301 \\
0,301 \\
0,301 \\
0,301 \\
0,301 \\
0,301\end{array}$ & $\begin{array}{l}\text { Valid } \\
\text { Valid } \\
\text { Valid } \\
\text { Valid } \\
\text { Valid } \\
\text { Valid }\end{array}$ \\
\hline $\begin{array}{l}\text { Variabel Y } \\
\text { Item } 1 \\
\text { Item } 2 \\
\text { Item } 3\end{array}$ & $\begin{array}{l}\text { Kemauan karyawan } \\
\text { Kesetiaan karyawan } \\
\text { Kebanggaan karyawan }\end{array}$ & $\begin{array}{l}0,611 \\
0,764 \\
0,566\end{array}$ & $\begin{array}{l}0,301 \\
0,301 \\
0,301\end{array}$ & $\begin{array}{l}\text { Valid } \\
\text { Valid } \\
\text { Valid }\end{array}$ \\
\hline $\begin{array}{l}\text { Sumb } \\
\text { Berc } \\
\text { hasi } \\
\text { indik } \\
\text { koef } \\
\text { sehi } \\
\text { varic } \\
\text { pros } \\
\text { b. U } \\
\text { ukur } \\
\text { men }\end{array}$ & $\begin{array}{l}\text { ata: diolah } \\
\text { rkan tabel diatas, dari } \\
\text { validitas ternyata semua } \\
\text { variabel valid karena } \\
\text { korelsinya > } 0,3 \text {, } \\
\text { semua indikator } \\
\text { dapat diikutkan dalam } \\
\text { elanjutnya. } \\
\text { liabilitas } \\
\text { engajuan keandalan alat } \\
\text { dalam penelitian ini } \\
\text { nakan metode cronbach }\end{array}$ & & $\begin{array}{l}\text { a. Tuju } \\
\text { ah untu } \\
\text { ndalan } \\
\text { litian. } \\
\text { takan } \\
\text { sien a } \\
\text { ggunak } \\
\text { bach d } \\
\text { ıan S } \\
\text { dape } \\
\text { vah ini }\end{array}$ & $\begin{array}{l}\text { dari uji reliabilitas } \\
\text { lengetahui tingkat } \\
\text { dari intrumen } \\
\text { /ariabel dapat } \\
\text { landal apabila } \\
>0,5 \text {, dengan } \\
\text { metode Alpha } \\
\text { an menggunakan } \\
\text { Program Versi } \\
\text { ilihat pada tabel }\end{array}$ \\
\hline
\end{tabular}

Tabel Hasil Uji Reliabilitas

\begin{tabular}{|c|c|c|c|c|}
\hline Variabel & Keterangan & $\mathrm{r}$ alpha & $r$ tabel & Keterangan \\
\hline $\begin{array}{l}\text { Variabel X } \\
\text { X1 } \\
\text { X2 }\end{array}$ & $\begin{array}{l}\text { Perencanaan } \\
\text { Peramalan }\end{array}$ & $\begin{array}{l}0,793 \\
0,759\end{array}$ & $\begin{array}{l}0,301 \\
0,301\end{array}$ & $\begin{array}{l}\text { Handal } \\
\text { Handal }\end{array}$ \\
\hline Variabel Y & $\begin{array}{l}\text { Komitmen } \\
\text { karyawan }\end{array}$ & 0,653 & 0,301 & Handal \\
\hline
\end{tabular}

Sumber data : diolah

Semua variabel penelitian

yang terdiri-dari perencanaan

(X1) peramalan (X2) dan komitmen karyawan (Y) mempunyai tingkat kehandalan untuk digunakan dalam penelitian karena koefisien alpha > 0,5.

\section{- Analisa Statistik}

Berdasarkan hasil perhitungan dengan menggunakan program SPSS versi 21.0 maka persamaan regresi linear berganda dari penelitian sebagai berikut :
a. Persamaan Regresi Linear Berganda

Tabel Coefficients ${ }^{a}$

\begin{tabular}{|c|c|c|c|c|c|c|c|c|}
\hline \multirow[t]{2}{*}{ Model } & \multicolumn{2}{|c|}{$\begin{array}{l}\text { Unstandardized } \\
\text { Coefficients }\end{array}$} & \multirow{2}{*}{$\begin{array}{l}\begin{array}{l}\text { Standardized } \\
\text { Coefficients }\end{array} \\
\text { Beta }\end{array}$} & \multirow[b]{2}{*}{$\mathbf{t}$} & \multirow[b]{2}{*}{ Sig. } & \multicolumn{3}{|c|}{ Correlations } \\
\hline & B & $\begin{array}{l}\text { Std. } \\
\text { Error }\end{array}$ & & & & $\begin{array}{l}\text { Zero- } \\
\text { Order }\end{array}$ & Partial & Part \\
\hline 1 (Constan) & ,748 & ,539 & & 1,390 & ,172 & & & \\
\hline
\end{tabular}




\begin{tabular}{|l|l|l|l|l|l|l|l|l|}
\hline X1 Perencanaan &, 568 &, 157 &, 468 & 3,623 &, 001 &, 631 &, 497 &, 410 \\
\hline X2 Peramalan &, 277 &, 106 &, 339 & 2,624 &, 012 &, 564 &, 383 &, 297 \\
\hline
\end{tabular}

a. Dependent Variable: $Y$

Sumber Data : diolah

Berdasarkan tabel cofficients, dapat disusun persamaan regresi berganda sebagai berikut :

$\mathrm{X} 2+\mathrm{E}$
Nilai konstanta sebesar ,748 hal ini berarti bahwa pada saat $X$ sama dengan nol maka kinerja sebesar ,748. Koefisien variabel Perencanaan (X1) sebesar ,568 dan peramalan (X2), 277

Tabel Nilai R Model Summary

\begin{tabular}{|c|c|c|c|c|c|c|c|c|c|}
\hline \multirow[t]{2}{*}{ Model } & \multirow[t]{2}{*}{$\mathbf{R}$} & \multirow{2}{*}{$\begin{array}{l}\text { R } \\
\text { Square }\end{array}$} & \multirow{2}{*}{$\begin{array}{l}\text { Adjusted } \\
\mathbf{R} \\
\text { Square }\end{array}$} & \multirow{2}{*}{$\begin{array}{l}\text { Std. } \\
\text { Error } \\
\text { ofthe } \\
\text { Estimat } \\
\text { e }\end{array}$} & \multicolumn{5}{|c|}{ Change Statistich } \\
\hline & & & & & $\begin{array}{l}\text { RSquare } \\
\text { Change }\end{array}$ & F Change & $\begin{array}{l}\text { df } \\
1\end{array}$ & $\begin{array}{l}\text { df } \\
2\end{array}$ & $\begin{array}{l}\text { Sig.F } \\
\text { Change }\end{array}$ \\
\hline 1 &, $698^{a}$ & ,487 & 461 & 35417 & ,487 & 18,953 & 2 & 40 & ,000 \\
\hline
\end{tabular}

a. Predictors : (Constant), X1(perencanaan), X2(peramalan)

b. Dependent Variable : $Y$

Sumber data : diolah dari lampiran 3

Hasil perhitungan $\mathrm{R}$ pada table diatas, yaitu menunjukkan gambaran pengaruh antara variable bebas yang terdiri-dari perencanaan (X1), peramalan (X2) terhadap variable terikat yaitu komitmen karyawan ( $\mathrm{Y}$ ). Nilai $\mathrm{R}$ sebesar 0,698 atau $69,8 \%$ yaitu menggambarkan hubungan antara variabel bebas terhadap variabel terikat bersifat searah atau kuat. Sedangkan $\mathrm{R}$ square atau determinan $\mathrm{R}$ sebesar 0,487 atau $48,7 \%$ pengaruh secara simultan sedangkan sisanya sisanya $\quad(100 \%-48,7 \%=51,3 \%)$ dipengaruhi faktor lain yang tidak diteliti dalam penelitian ini.

\section{- Uji Hipotesis}

Uji F

Untuk mengetahui pengaruh secara simultan atau secara bersamasama variabel perencanaan (X1) dan peramalan (X2) terhadap variabel terikat komitmen karyawan ( $Y$ ) maka dapat dilihat dari hasil perhitungan dengan menggunakan uji $\mathrm{F}$ sebagai berikut :

Tabel Uji F

\begin{tabular}{|c|l|l|l|l|l|}
\hline model & Sum of Squares & Df & $\begin{array}{l}\text { Mean } \\
\text { Square }\end{array}$ & $\mathbf{F}$ & Sig. \\
\hline $1 . \quad$ Regression & 4,755 & 2 & 2,377 & 18,953 &, $000^{\mathrm{b}}$ \\
\hline Residual & 5,018 & 40 &, 125 & & \\
\hline Total & 9,772 & 42 & & & \\
\hline
\end{tabular}

a. Dependent Variabel : Y (komitmen karyawan)

b. Predictor : (Constant), X2 (peramalan), X1 (perencanaan)

Sumber data diolah

Dari hasil perhitungan diperoleh $\mathrm{F}$ hitung sebesar 18,953 dan apabila dikonsultasikan dengan $\mathrm{F}$ tabel sebesar 3,23 jadi $F$ hitung lebih besar dari $F$ tabel maka hipotesa penulis bahwa diduga variabel perencanaan (X1) dan peramalan (X2) secara bersama-sama mempengaruhi variabel terikat yaitu komitmen karyawan (Y) dapat dibuktikan kebenarannya.

Uji t 
Berdasarkan hasil perhitungan diperoleh t hitung untuk variabel perencanaan (X1) sebesar 3,623 dan peramalan (X2) sebesar 2,624 dan kalau dikonsultasikan dengan $t$ tabel sebesar 2,021 sehingga $t$ hitung $>\mathrm{t}$ tabel. Dengan demikian dapat disimpulkan bahwa variabel perencanaan (X1) dan peramalan (X2) berpengaruh terhadap komitmen karyawan $(\mathrm{Y})$ dapat dibuktikan kebenarannya.

Dari hasil perhitungan dengan menggunakan uji t, ternyata dari kedua variabel tersebut, variabel perencanaan (X1) nilai t nya paling besar. Dengan demikia variabel perencanaan (X1) adalah variabel yang paling dominan mempengaruhi komitmen karyawan $(\mathrm{Y})$ PT. BPRS SARANA PRIMA MANDIRI.

\section{KESIMPULAN DAN SARAN} - Kesimpulan

Berdasarkan hasil penelitian dan pembahasan mengenai pengaruh perencanaan dan peramalan untuk membangun komitmen karyawan maka keimpulan dari hasil penelitian ini adalah sebagai berikut:

1. Dari hasil perhitungan dari variabel bebas yaitu diperoleh $F$ hitung sebesar 18,953 dan apa bila dikonsultasikan dengan $F$ tabel sebesar 3,23 jadi $F$ hitung lebih besar dari $\mathrm{F}$ tabel maka diduga variabel perencanaan (X1) dan peramalan (X2) secara bersama-sama mempengaruhi variabel terikat yaitu komitmen karyawan (Y) dapat dibuktikan kebenarannya. .

2. Dari hasil perhitungan variabel yang paling mempengaruhi yaitu perencanaan $(\mathrm{X} 1)$ dengan nilai $\mathrm{t}$ hitung 3,623 berpengaruh terhadap variabel terikat yaitu komitmen karyawan $(\mathrm{Y})$ dengan nilai $R$ sebesar 0,698 atau $69,8 \%$ dapat dibuktikan kebenarannya.

\section{- Saran}

Dari hasil penelitian mengenai pengaruh perencanaan dan peramalan untuk membangun komitmen karyawan pada PT. BPRS SARANA PRIMA
MANDIRI pamekasan, maka saran-saran dari peneliti adalah sebagai berikut :

1. Diharapkan PT. BPRS SARANA PRIMA MANDIRI pamekasan memperhatikan tentang perencanaan pada saat merekrut karyawan dimasa yang akan datang karena berdasarkan hasil penelitian perencanaan berpengaruh terhadap komitmen karyawan.

2. Hendaknya PT. BPRS SARANA PRIMA MANDIRI pamekasan pada saat melakukan perencanaan perekrutan karyawan harus disesuaikan dengan kemampuan karyawan yang memiliki komitmen siap bekerja pada perusahaan.

\section{DAFTAR PUSTAKA}

Armstrong, Michael. 2005. Manajemen Sumber Daya Manusia. PT ElexmediaKomputindo. Jakarta

Danim. 2000. Pengantar Study Penelitian Kebijakan. Jakarta : Bumi Aksara.

Greenberg, \& Baron. 2000. Perilaku Organisasi. Jakarta : Prentice Hall

Hakim, Rachman. 2011. Analisis Perilaku Penawaran Kredit Bank BPR di Malang (Studi Kasus PT. BPR Armindo Kencana Malang). Skripsi. Fakultas Ekonomi Universitas Negeri Malang.

Hakim, Rachman. 2016. Meninjau Kembali Seberapa Penting Target Inflasi BankIndonesia Dalam Mengontrol Laju Inflasi. Ekuitas: Jurnal Ekonomi dan Keuangan Volume 20, Nomor 1, Maret 2016 : $53-71$.

Meldona,2009. Manajemen Sumber Daya Manusia, Perspektif Integratif. Malang.

Malayu S.P. Hasibuan EDISI REVISI. Manajemen Sumber Daya Manusia, Bumi Aksara. Jakarta. 2012

Sedarmayanti. Manajemen Sumber Daya Manusia, Reformasi Birokrasi dan Manajemen Pegawai Negeri Sipil. Bandung :PT Aditama. 2007. 
Wilson Bangun,Manajemen Sumber Daya Manusia, Penerbit ERLANGGA Jakarta. 2012

Rivai Veithzal. 2013. Manajamen Sumber Daya Manusia Untuk Perusahaan : dari Teori dan Praktik. PT. Raja Grafindo Persada, Jakarta.

Sugiyono. 2001. Metode Penelitian Administrasi, Penerbit Alfabeta Bandung

2002. Statistik Untuk Penelitian Dan Aplikasinya dengan SPSS 10.00 for windows. Alfabeta, Bandung.

2008. Statistika Untuk Penelitian. Penerbit CV. Alfabeta, Bandung.

2012. Metode Penelitian Kuantitatif, Kualitatif dan R\&D. Cet XVII. Penerbit Alfabeta, Bandung.

2006. Metode Penelitian Bisnis,

Alfabeta, Bandung 